\section{Analysis of Development of Archiving Regulation from Time to Time in Indonesia}

\section{Rhoni Rodin $^{1}$ and Mia Romiati ${ }^{2}$}

${ }^{1}$ Perpustakaan IAIN Curup/Program Studi Ilmu Perpustakaan dan Informasi Islam IAIN Curup

${ }^{2}$ Universitas Islam Negeri Raden Fatah Palembang

\section{Abstract}

Background of the study: This research belongs to the literature study since it is carried out by exploring information and documentation relating to archiving regulations

Purpose: This study aims to analyze the development of archiving regulations in Indonesia from time to time.

Method: Analyzing data using descriptive analysis methods.

Findings: The results showed that the development of archiving regulations in Indonesia showed a positive trend, as this was shown by the issuance of several regulations relating to archival issues from the Dutch colonial era and the independence of Indonesia in 1945 up until the issuance of Law No. 43 of 2009 during the reform era recently.

Conclusion: All archiving laws or regulations are basically for the existence of archives and archives very important for society, government and the Indonesian Nation.

Keywords: Archive, archiving regulation, Indonesia
Paper Type:

Research Paper

Submitted 18 March 2019

Accepted 09 April 2019

Online 30 September 2019

* Correspondence:

Rhoni Rodin

E-mail:

rhoni.rodin@iaincurup.ac.id

To cite this document:

Rodin, R., Romiati, M. (2019). Analysis of development of archiving regulation from

time to time in Indonesia. Record and Library Journal, 5 (1), 90 - 105. 


\section{Introduction}

The development of archiving regulations in Indonesia reflects a dynamic development of a very unique and dynamic writing tradition. The uniqueness lies in the history of written cultural development in Indonesia, both concerning the recording media used and in terms of managing the recording media themselves. The dynamics grew as a result of socio-political developments from the days of the rulers of kingdoms in the archipelago, the period of western social political penetration in the colonial era, the implementation of the colonial political system, and the situation in the postcolonial political system after the 17th of August 1945. The progressiveness of the dynamics is more evident in the development of the archival system following the issuance of Law Number 7 of 1971 concerning the Principal Provisions of Archives. This situation has resulted in the history of archives in Indonesia being rich in repertoire of archive management systems and legal products in the field of archiving.

To understand the development of archiving regulations in Indonesia, adequate knowledge is needed both in the field of history and the tradition of archiving in the broadest sense. Historical insight is needed to understand the dynamic growth of government administration from the precolonial period to the reign of the Unitary State of the Republic of Indonesia. With this understanding, it is expected to describe the diverse administrative system relationships in Indonesia with the archival system that developed in each period of Indonesian history. An understanding of archival traditions is needed in order to understand the dynamics of the systems and regulations of archives that thrived in Indonesia.

During the Dutch colonial period, Western administration and archival systems were implemented in both governmental and private institutions. As a result, Western archival system thrived well within institutions, agencies, and companies, both private and government, such as in the railroad company, plantations, and banking services. The government's need to provide public services to a society that was accustomed to the written tradition gave rise to a high awareness of the importance of archival records and management. At each agency there was a special officer who managed the archives, and in the context of the colonial government, there was an archivist of the state who was responsible for the management of the colonial government archives.

The growth of government administration that increasingly became more complex and orderly had led to the rapid growth of archive accumulation and at the same time it required an increase in the quality of evidence of accountability for the implementation of official functions. Archival accumulation growth that was so high must be overcome with regular depreciation and the need for accountability quality required an efficient depreciation system which fulfilled the applicable legal provisions so that archives that were still needed for operational interests and permanent useful value records could be preserved as the nation's collective memory. Therefore, there was a need for a nationally coordinated filing system and this had become the driving force for the issuance of legislation bill on Archival Principal Provisions in 1971. The magnitude of the Indonesian government's attention to archival issues was evident with the issuance of Law No. 43 of 2009 about archives, where the scope and discussion were broader and more detailed than the previous regulations. The issuance of the law was not only the basis of fostering the national archival system but had also become a trigger for the growing awareness of archiving in communities that already considered the written tradition as part of life.

Based on the above conditions of the development of archival regulations in Indonesia above, the dynamics of regulatory developments concerning archiving in Indonesia can clearly be seen. This is what prompted the researchers to be interested in analyzing the development of archival regulations in Indonesia. It is expected that the results of the analysis in this paper are able to show the dynamics of archival regulations in Indonesia.

The importance of this paper basically departs from the hope that it will be useful and contribute to archival management in Indonesia, by both government and private institutions. Practically the results of this study are also expected to be taken into consideration by the government, in this case the

To cite this document:

Rodin, R., Romiati, M. (2019). Analysis of development of archiving regulation from

time to time in Indonesia. Record and Library Journal, 5 (1), 90 - 105. 
National Archives of the Republic of Indonesia, and by regional archival offices and institutions that require archives. By looking at the dynamics of the development of archival regulations, it can be used as material in evaluating the existing archival regulations. Likewise for the legislators, it is expected that this paper can be a consideration in analyzing existing archival regulations in Indonesia from time to time.

Based on the description above, the researchers are interested in analyzing how the development of archival regulations happened in Indonesia from time to time. With this purpose, this paper is hoped to be able to add to the treasure of knowledge in the field of archiving, and to foster an awareness of the importance of the existence of archives in the administration of statehood.

\section{Research Method}

This study belongs to the type of literature study conducted by looking for theoretical references that are relevant to cases or problems found. Literature study is a method used to collect data or sources related to the topic raised in a study. Literature studies can get sources from various things, such as journals, documentation books, internet and libraries. Theoretical references obtained by means of literature study are used as the basic foundation and the main tools for research practice in the middle of the field. The types of data used by the authors in this study are primary data by conducting observations, and secondary data obtained from journals, documentation books, and the internet. Documentation is a method for finding documents or data that are considered important through newspaper/magazine articles, journals, references, brochures, and documentation books, as well as through electronic media, namely the Internet, which has to do with the implementation of this research. The literature study in this research is to gather information relating to regulations in the field of filing from time to time in Indonesia. The data that have been obtained are then analyzed by descriptive analysis method. Descriptive analysis method is done by describing the facts which are then followed by analysis, not merely describing, but also providing sufficient understanding and explanation.

\section{Result and Discussion}

\section{The Terminologies of Archives and Archive Institutions}

The meaning of the archive in its terminology can be divided into two, namely the continental European terminology and the terminology of the United Kingdom / Anglo-Saxon and its colonies. In European countries, especially Germany, the Netherlands and France as pioneers of archival theory and methodology thinking, the term archives refers to all types of manuscripts made or received by an agency in the implementation of official functions. For archives that are still used directly to support the completion of administrative / operational processes, it is referred to as a dynamic archive, and archives that have not been used to support operational activities but still have a continuous use value are referred to as static archives. Dynamic archives which are still used for the completion of a matter or for correspondence are known as active records (Syauki Hadiwardoyo: 2014).

In an Anglo-Saxon terminology, all manuscripts made or received in the execution of official functions of an agency are known as "records". In detail, it can be distinguished by the term current record for archives that are still active, semi / non-current records for inactive records and public records for static archives (T.R. Schellenberg, 1956: 16). Thus, in the United Kingdom and its colonies, the term archives are not recognized, but there is the term record which refers to all types of manuscripts that were made or received in the implementation of official functions.

According to Wursanto (2006), archives are all letters, manuscripts, scripts, files, and the like, whether produced or received by organizations or companies in any form or pattern, whether in single or group conditions, which still have useful values, both for the present and for the future. Furthermore Sedarmayanti (2008) suggests that the term archive includes three meanings, namely: 1). Collection of stored manuscripts or documents; 2). Building (space) for the storage of a collection of manuscripts or documents; 3). Organizations or institutions that manage and store a collection of manuscripts or

To cite this document:

Rodin, R., Romiati, M. (2019). Analysis of development of archiving regulation from

time to time in Indonesia. Record and Library Journal, 5 (1), 90 - 105. 
documents.

Barthos (2003) states that an archive (record) can be understood as each written record in the form of an image or chart that contains information about a subject (subject matter) or an event that is made by people to help the memory of those people. Meanwhile, according to The Liang Gie (2000) archive is a collection of scripts that are stored systematically due to their usefulness, so that whenever they are needed they can be quickly retrieved.

The terms archives and records as having different characteristics emerge as a result of new approaches in the management of modern records driven by American archival thinkers. With the development of the life cycle approach in the management of records, the term "archive" refers to static documentation and "records" for the dynamic one. An archive is part of a record that is considered to have a permanent use value. With the emergence of a new approach called a record continuum the strict boundary between the profession of record management and archive management is no longer appropriate since for the sake of operational efficiency the archive management agency must be designed from the moment it is created to preserve and use it as a static archive. This is already a necessity, especially in the case of electronic records management because when an electronic text has the status of an archive, the collection must have a management and use value and cannot wait in minutes. With a variety of approaches, it shows that the theory and management of archives is developing and always leads to the demands of increasing the operational efficiency of agencies in their time.

Furthermore, the understanding of archive management institutions as referred to in Law Number 7/1971 is as an archival organization (Law No. 7/1971: Article 8). In the organizational structure of government, what is meant by archiving institutions are archival units at state institutions and central and regional government agencies as well as the National Archives of the Republic of Indonesia both in the Indonesian capital city and in the provincial capitals throughout Indonesia. With the enactment of Law Number 22 of 1999 concerning Regional Governance, the status of the Regional National Archives in the provincial capital changed to a regional archival body.

Law No. 43 of 2009 on Archives states that Archive is a recording of activities or events in various forms and media in accordance with the development of information and communication technology made and accepted by state institutions, regional governments, educational institutions, companies, political organizations, community organizations, and individuals in the implementation of societal, national and state livelihood. Meanwhile, Archiving is matters relating to the archive.

Based on the above explanation, it can be understood that Archive is a collection of documents in the form of letters, recordings, and videos that can be used as authentic evidence in an organization for the future and stored using a particular system so that it can be retrieved quickly and precisely. Meanwhile, Archiving is a process of the activities of receiving, recording, and storing using a particular system, maintenance, effective and efficient rediscovery, and depreciation, as well as destruction of letters / scripts.

\section{Development of the Archive Management Institutions}

The Republic of Indonesia National Archives (ANRI) has historical roots in the days of the Dutch East Indies colonial government. To accommodate the interests of archival management, the Dutch East Indies government then formed an archival institution under the name of the State Archives in Batavia or "Batavia te Landsarchijf", headed by an archivist of the country named JA van der Chijs in 1892. The purpose was to manage the inactive archives of the Dutch East Indies government so that it could be used for government, public and for research purposes in the context of cultural development (Syauki Hadiwardoyo: 2014). The idea of the function of the State Archives was the rationale used when the institution changed its name after the independence of Indonesia to the National Archives of the Republic of Indonesia in 1971 as stated in Law No. 7 of 1971 Article 8. The change of name also meant an addition of a new function, from merely managing static records to fostering a national archiving system as well.

To cite this document:

Rodin, R., Romiati, M. (2019). Analysis of development of archiving regulation from

time to time in Indonesia. Record and Library Journal, 5 (1), 90 - 105. 
The position of the Republic of Indonesia National Archives as the supervisor of the national archival system requires an integrated archival institutional system at the level of state institutions and government agencies at both the central and regional levels. Therefore, a network of archival institutions consisting of the Republic of Indonesia National Archives in the national capital, archival units at government agencies at the central level and local government archival units at the provincial and regency / city levels was built. Thus, there is a network system of archiving guidance and integrated archive management nationally so that the implementation of archive management can be carried out efficiently and meet the need for increased operational efficiency of agencies, as well as preservation and utilization of archives that have value for national accountability.

Archive management in Indonesia develops dynamically. It was started during the colonial period when the Dutch East Indies government formed the State Archives with the name "Batavia te Landsarchijf", with the intention that the archives of colonial government institutions that were no longer operational could be managed by the archiving institutions. Therefore, the first work program was to organize the archives of the colonial government at the central level so that they could be used for the public interest and then proceeded to acquire archives from government offices in the area.

The structuring program began with the arrangement of archives of the Algemene Secretarie or the State Secretariat during the colonial administration, followed by structuring the archives of state institutions and central government agencies. Among these government institutions are Departement van Justitie, Departement Financien, Departement van Binnenlandsch Bestuur, Departement van Onderwijs, Eerendienst en Nijverheit, Departement van Openbaar Werken, and Departement van Verkeer en Waterstaat, and archives of the British Government in Java (Engels Tussen Bestuur) and other institutions which were instruments of the VOC government (Regering Almanak, 1920: Deel 1). After that, the arrangement continued for the archives of representative institutions of the Dutch East Indies abroad, which had been acquired by the State Archives in Batavia.

The subsequent program was the acquisition of archives of the Dutch East Indies government institutions throughout Indonesia alongside the archives of VOC representative offices abroad. The program took place since the last decade of the 20th century until 1917 when World War I erupted. VOC representative offices included the cities of Hirado (Jepan), Ceylon (Sri Lanka), West Indies, and Cape de Goed Hope (South Africa). This acquisition ended in 1917 when it was only partially resolved, especially the archives originating from the local governments and the residencies of the colonial government which were considered important such as the governments of Makassar, Banda Timor, Bali-Lombok, Surabaya, Semarang, Tangerang, Riau, Palembang, Aceh, Borneo, and others. Therefore, the repertoire of the colonial archives, especially the regional archives, was not very complete and even it was estimated that some of them did not reach Batavia because of the disruption of the shipping security situation before World War I.

The Batavia State Archives was a national archival institution during the colonial government whose main function was to manage static archives only. The institution did not have vertical institutions in the area so it was a necessity for all Dutch East Indies government agencies to submit static archives which were created as recorded information in their own institutions to the State Archives in Batavia. There is no stand-alone archiving institution in the area and the archives created within the relevant government agency are the responsibility of the relevant local government archival unit.

At the beginning of the period the government of the Republic of Indonesia, archivist management institutions did not experience significant changes. In connection with the handover of the sovereignty of the Dutch East Indies colonial government to the government of the Republic of Indonesia, the position of the State Archives in Batavia was maintained and placed under the new republic's State Secretariat. This position changed in the late decade of the 50 s following the Presidential Decree of 5 July 1959 which resulted in the placement of State Archives under the Ministry of Education and Culture. Political changes ahead of the outbreak of the G30S / PKI coup d'etat event, State Archives were placed under the Compartment of the Ministry of Relations with the

To cite this document:

Rodin, R., Romiati, M. (2019). Analysis of development of archiving regulation from

time to time in Indonesia. Record and Library Journal, 5 (1), 90 - 105. 
People (Menko Hubra), as an independent institution that was directly responsible to the ministry.

With the formation of the Ampera Cabinet in 1967, the State Archives were placed under the Republic of Indonesia Secretariat. This position was strengthened by the issuance of Law No. 7/1971 concerning Archival Principal Provisions, which established the State Archives to become the National Archives of the Republic of Indonesia (ANRI). To strengthen the Law, Presidential Decree Number 26 of 1974 was issued which stipulated the National Archives of the Republic of Indonesia as a NonDepartmental government institution that was directly responsible to the President, as stated in Presidential Decree Number 26 of 1974 in Article 1. The implementation of its activities was coordinated by Minister of State Secretary. This continued until the fall of the New Order government in 1998.

Since the fall of the New Order government until 2000 the status of the National Archives had not been formally changed and was even more capable of carrying out its functions as a nonministerial government institution that was directly responsible to the President. Furthermore, along with the formation of the Gotong Royong (Mutual Cooperation) Cabinet, the formal status of the Indonesian National Archives did not change, but the implementation of its duties was coordinated by the Ministry of Administrative Reform (PAN), and this continues to this day.

In accordance with the provisions of Law No. 7/1971, the government archival institution consists of the Indonesian National Archives at the central government level, the Regional National Archives for each Level I Region and archival units of government agencies at the central and regional levels including the Regional Archives Office which is the archive unit of the Level I regional government. National Archives both in the national capital and in the provincial capital have the function of fostering a national archival system and preservation and management of acquired static records from state institutions and government bodies, while the Regional Archives Office implements the function of fostering the archival system and inactive archive management created in the internal environment of the relevant provincial government. Coordination of work is carried out between the National Archives of the Region and the Office of the Archives of the relevant provinces to guarantee the depreciation of the archives properly and the preservation of archives that are of value for national accountability are carried out properly in the area concerned. It is expected that there are efficient archive depreciation and systematic submission of valuable useful files from the Regional Archives Office to the Regional National Archives and Central Archive Institution Centers to the Republic of Indonesia's National Archives.

A very fundamental change in the field of national archiving took place in 2000 after the enactment of Law Number 22 of 1999 concerning Regional Governance. The national archives institutions in the region, called the National Archives of the Republic of Indonesia Regional Office, that had existed in nine provincial capitals were liquidated so that they became archival institutions of the relevant provincial regions. The position of regional archival institutions was then strengthened by the establishment of regency / city archival institutions so that there were autonomous archival institutions, namely the RI National Archive as a national archiving institution in the national capital, Provincial Archives Agency for the provincial level and office of Regional Archives for the regency / city government level.

The change in institutional status also brought about changes in the functions and duties of archival institutions. The Provincial Archives Office was upgraded by adding new functions as static archive managers following the liquidation of the Regional National Archives to become part of the provincial government, obtaining a new name, the Provincial Archives Agency. The term Provincial Archives Office was abolished and then designated as the name of the regency / city government archival institution. The liquidation process was completed in 2001. Thus, the National Archives of the Republic of Indonesia (ANRI) no longer had vertical agencies in the regional level, so the logical consequence was that the relationship between ANRI and the regional archiving institutions is limited to system and professional development.

Outside the government institutions in Indonesia, there are also private archival institutions. This

To cite this document:

Rodin, R., Romiati, M. (2019). Analysis of development of archiving regulation from

time to time in Indonesia. Record and Library Journal, 5 (1), 90 - 105. 
is possible because the applicable legislation does not regulate the existence of archival institutions managed by agencies or non-governmental organizations, as stated in Law Number 7 of 1971 in Article 4. Therefore, private archiving institutions in Indonesia are very diverse in terms of the repertoire of the archives managed and the management.

In general, there are 3 (three) types of archive management institutions, especially those related to the use of static archives. The first and the oldest type is the library. Some private libraries also manage static archives as part of their library services to the public, such as the Yogyakarta Palace Library and the libraries of religious institutions in general. Moreover, integrated archive and library services have long been part of public library services managed by the government, such as the National Library and the Provincial Library. In most provinces and regencies / cities in Indonesia, archiving and library institutions are put in one institution with the name of the Regional Library and Archive Services (formerly BPAD (Badan Perpustakaan dan Arsip Daerah), or the Regional Library and Archive Agency, while in a regency / city it is called the Regional Library and Archive Office).

The second type is the company archival institution, better known as the Company Archive Center. In general, every large company, especially those engaged in financial services and manufacturing, manages the archives that were created as a result of its activities in an archive center that provides services for operational and service purposes in the public interest. Among theses private archives are the archive centers of banking companies, cement factories, and heavy industrial plants.

Other private archival institutions are archival collectors who are generally lovers of art and famous figures who have various original professions. Many of art lovers and art entrepreneurs have galleries which also serve as showrooms and places to store archives that are collected because they are considered to have high artistic values. Most community leaders also have private libraries that store and present archival and library services in an integrated manner, especially for archives containing information about fields related to their professions. However, most of them manage archives as part of their business development and are not always managed as pure archival institutions.

A new phenomenon in the history of archiving Indonesia is the development of commercial filing institutions with the name of a commercial archive management center that grows in line with the operational efficiency requirements of a company. This archiving institution is generally in the form of a company that provides archival storage services from other companies which trust the management of their archives to commercial archive management institutions due to efficiency considerations. At present in Indonesia there are at least 25 companies engaged in archive management services (Syauki Hadiwardoyo: 2014).

Moreover, when speaking of the current era of information technology, the term digital archive comes to mind. Laksono (2017) in his research stated that based on the analysis related to the context of the use of digital technology in supporting the process of static archive media transfer, several hypotheses could be drawn. First is the importance of maintaining archives since it is still an active dynamic status, which is intended to facilitate processing. Secondly, the issue of authenticity of the archives must be of concern to the parties involved. This is important to be discussed further because one of the reasons for the preservation of static archives is the legal aspect they pose. Third, the process of transferring the media must still refer to Law Number 43 of 2009 concerning Archives, and Government Regulation Number 28 of 2012 concerning Implementation of this Law Number 43 of 2009. These references relating to processing archives must refer to the principle of original order and the principle of provenance. This is reiterated by Putranto (2017) who stated that in response to the development of information technology, most archival institutions should emphasize the technical dimensions such as the availability of infrastructure as well compliance with the standards and policies.

Indonesia, according to Suyadi (2011), should learn a lot in the Netherlands in terms of attention and the importance of good archive management. So far, the awareness about Indonesian archives is

To cite this document:

Rodin, R., Romiati, M. (2019). Analysis of development of archiving regulation from

time to time in Indonesia. Record and Library Journal, 5 (1), 90 - 105. 
still at minimum. The tradition of archiving among government offices is as meager as that of private institutions. Let alone for archives hundreds of years or decades back, archives in the past dozen of years are often incomplete and not well organized. Furthermore, Suyadi gave examples when we are looking for archival data about the number of passengers and ANS buses that departed from Padang to Jakarta in 1991, the Haluan newspaper editions published throughout 1952, the number of commercial tapes produced by Tanama Record and Sinar Padang in 1978, and the number of telecommunication kiosks in West Sumatra in 1987. According to Suyadi, it would be difficult to obtain these data if it could not be said to be impossible. The condition is certainly even worse we are looking for even earlier data. Such conditions are inversely proportional to what happened in Leiden, the Netherlands. In Leiden, archives are well organized and can be easily accessed if needed for scientific purposes. Another example of the not yet optimal archive management in Indonesia is shown by Abriani (2018) who studied the governance of village office archives in the Sumbang District area. She found out that the governance of village office records in the district was not yet in line with archival standards. She explained that the decisive factor for the success of archive management at the village office in the Sumbang District was the attention given by the leadership and the budget, because without these two factors, archive management activities cannot run optimally and the infrastructure needs will not be fulfilled.

The conditions described above are an illustration of how the archive management system exists in Indonesia. Meanwhile, when speaking of regulations and regulations, of course, it can be understood that there have been complete regulations as a legal umbrella for archive and archival activities, one of which is Law Number 43 of 2009.

\section{Analysis of the Development of Archival Regulations in Indonesia}

Historically, the issue of archives and archiving actually has begun since the development of the tradition of writing. After the tradition of writing people started making recordings of their activities both in the context of carrying out official and personal functions. Records of the implementation of these functions were then recognized as proof of transactions between the parties concerned and then stored as archives. In other words, the evidence of the transaction regulated the relationship between the parties involved in the transaction or can be said to form a legal bond. Departing from the understanding of these the legal aspects, then archiving continues to develop both in terms of the types of media records, formats, functions, and management systems.

The development of archival management in Indonesia shows its own peculiarities. The written tradition in Indonesia is closely related to the development of Indian calligraphy that entered Indonesia through religious channels. Therefore, archiving systems in this archipelagic nation are very unique, namely management in a closed room and purified in a religious building environment, and management in the place of informed objects whose archives were related to power. Archives related to religious activities in general were managed in an integrated manner with libraries in one of the complex buildings of the sacred building and generally contained recorded information about the administrative activities of the relevant institutions, religious teachings, and holy books. Therefore, it can be said that Indonesian archival institutions are actually archives of religious institutions.

Archives relating to governmental power were generally in the form of inscriptions and were managed individually by the stakeholders of the power in question. It is estimated that Queen Sima's inscription in Central Java is the oldest evidence for government archives and the model continued until the fifteenth century, namely at the end of the rule of the Majapahit Kingdom. With the establishment of Islamic power in Demak, the archival system of religious institutions developed in the center of power. The direct influence of these changes was still felt until the twentieth century, as reflected in the tradition of the palace which considered that certain books / archives were sacred. The royal archive management system was combined with the management of books written by scholars or royal poets, where archives were managed for the benefit of developing the culture of the kingdom in question. 
According to Syauki Hadiwardoyo (2014) the entry of Western powers in Indonesia had a major influence in the management of archives. The Western writing tradition that developed along with the implementation of colonial administration in various regions was followed by the implementation of the archival system that was applicable in the Western nation concerned. The British, who came to power in Indonesia between 1811 and 1816 (partly until 1826) introduced a system of archives in the United Kingdom, and the Dutch who ruled until 1942 introduced the Dutch archival system, including the Kaulbach system for dynamic archives and the Van der Chijs system for static archives. Even in the modern archival system of the Republic of Indonesia, the influence of the Dutch archival system still feels thick with the use of the Dutch manual book for the arrangement and description of archives in the management of static records in the National Archives of the Republic of Indonesia (ANRI). With the entry of Western civilization, the Western archival system also entered, and it was getting stronger with Indonesia's attachment as a member of the International Council on Archives.

The dynamics of institutional development, management, and filing regulations result in the emergence of the need to regulate archive management both institutionally and nationally. Institutionally, it includes arrangements for technical aspects and archive management methods that are considered to meet the needs of increasing operational efficiency of agencies and at the same time the preservation needs of archives that are considered to have use values for broader interests (research uses) in the context of carrying out the life of nation and state. In this case, arrangements are needed regarding the management of archives in institutions / organizations creating archives (creating agencies) in order to manage records efficiently for the sake of accountability and for the sake of preserving the nation's collective memories in the framework of national accountability.

National arrangements are needed in the framework of preserving archives as the nation's collective memories so that in the management of records there is a clear link between state institutions and government agencies both in the management of dynamic and static archives. In the management of dynamic archives, there is a need for archival norms and standards that apply nationally to ensure that the depreciation of archives that apply to all state institutions and government agencies is carried out with the same benchmarks so that uncontrolled archive destruction can be prevented. Thus the depreciation of archives can be carried out systematically and measurably and produce static archives of high quality for the nation's collective memories and as evidence of national accountability to future generations. For this reason, it is necessary to have a clear path in the depreciation of the archives both from processing units to the archival unit of an archiving creator, destruction of archives that have expired their shelf life and value and submission of archives that have permanent use value to archival institutions to be managed as static archives.

National archival management arrangements are needed to ensure the preservation of the nation's collective memories as carefully as possible and their use in the public interest and the implementation of the life of the nation and state. This is needed in the context of national institutional coordination and archival service standards both between the central government agencies and regional government agencies and between the provincial government and the regency / city government. With the existence of regulations (legal provisions) concerning the technical aspects of archival management and aspects of institutional coordination, it is hoped that the efficient management of archives and the preservation and utilization of effective archives will be carried out nationally. These regulations (legal provisions) are absolutely needed by every country including Indonesia.

Archival regulations in Indonesia have been far behind when compared to other countries. Suyadi (2011) for example said that Indonesia should learn a lot from the Netherlands in terms of attention and the importance of good archive management. So far, the awareness of the Indonesian archives has still been meager. The tradition of archiving in government offices is as weak as that of private institutions. Let alone for archives hundreds of years or decades back, archives in the past dozen of years are often incomplete and not well organized. Furthermore, Suyadi gave an example when we will look for archival data about the number of passengers and ANS buses that departed from Padang to Jakarta in 1991, the Haluan newspaper editions published throughout 1952, the number of

To cite this document:

Rodin, R., Romiati, M. (2019). Analysis of development of archiving regulation from

time to time in Indonesia. Record and Library Journal, 5 (1), 90 - 105. 
commercial tapes produced by Tanama Record and Sinar Padang year 1978, and the number of telecommunication kiosks in West Sumatra in 1987. According to Suyadi, these data would be difficult to obtain if it could not be said to be impossible. The condition is certainly even worse when we are looking for data that are even earlier. Such conditions are inversely proportional to what happened in Leiden, Netherlands. In Leiden the archives are well organized and can be easily accessed if needed for scientific purposes. Suyadi's statement was reinforced by Pattrick (2006) in his article discussing the findings of a cross-sectional study conducted between 2004 and 2005 to determine how far archiving institutions in the East and South African Regional Branches of the International Council for Archives (ESARBICA) managed their public archives and documents. It is important that public records and archives be managed efficiently and effectively. The law mandating archival institutions to manage records through their life cycles is not comprehensive in some cases.

Furthermore, in the context of universities in Indonesia, for example, Lolitasari (2015) in her research stated that an Indonesian university should have built an archive center. Likewise, in terms of archival activities, they have not been done optimally. This is indicated by the lack of clarity of the unit or part which must be responsible for the storage and management of the university's archives. The case of the loss of archives, the results of research, plagiarism of papers, and falsification of diplomas often found in universities are some of the problems of file management in universities in Indonesia.

In the history of Indonesia, the growth of filing regulations has begun since the Dutch colonial era. Archival regulations that are very meaningful, and very influential in Indonesia's filing system, are laws that regulate the state treasury of the Indische Comptabiliteit Wet (ICW). This law is basically still valid until now so that regulations in the field of filing must still pay attention to the provisions contained in the ICW.

The law specifically regulates the field of filing for the first time published in 1971, namely Law Number 7 of 1971 concerning the Basic Provisions of Archives. As a law, this legal regulation regulates a very broad aspect, including the management of records and institutions nationally. In it is defined the definition of archives, archival organizations, archival staff, and the National Archives of the Republic of Indonesia as a national archiving and archival management agency (Law No. 7/1971: Article 1, Article 2, Article 6, and Article 8) .

The birth of Law No. 7 of 1971 concerning the Basic Provisions of Archives was followed by the issuance of Government Regulation No. 34 of 1979 concerning Depreciation of Archives. The regulation regulates the depreciation of records widely within the state institutions and government agencies. It is obligatory for each government agency to shrink the archive systematically by referring to the Archive Retention Schedule set by the relevant archiving agency as stated in article 4 of PP No. 34 of 1979. In the event that the agency in question does not yet have an Archive Retention Schedule then the file depreciation is the relevant agency can be carried out in accordance with the Circular of the Head of the Republic of Indonesia National Archives Number: SE / 02/1983. The provisions of the Government Regulation were then followed by the issuance of various technical regulations stipulated by the Head of the Indonesian National Archives.

Legislation in the field of filing concerning the management of company records is published separately under the name Law Number 8 of 1997 concerning Company Documents. The law emerged as a reaction to the implementation of file depreciation which was considered very slow, so that the issuance of the regulation was expected to overcome the lag. However, the new law cannot be implemented in an orderly manner because it contains several aspects that are contrary to the provisions of the court case. Law No. 8 of 1997 is an initiative of financial institutions incorporated in the national banking forum.

The development of filing regulations in Indonesia has shown a positive trend, this is marked by the birth of Law No. 43 of 2009 concerning Archives. This law has discussed the scope and scope of archives that are more extensive and detailed. Then also issued Government Regulation Number 28 of 2012 concerning Implementation of Law Number 43 of 2009 concerning Archives. In fact, other

To cite this document:

Rodin, R., Romiati, M. (2019). Analysis of development of archiving regulation from

time to time in Indonesia. Record and Library Journal, 5 (1), 90 - 105. 
regulations also emerged in order to complement the filing regulations in Indonesia, both ministerial regulations and the Head of the RI National Archives regulations, and other regulations relating to archives and archives. For more details, how to analyze comparative filing regulations in Indonesia, the following author will provide an analysis between Law Number 43 of 2009 concerning Archives with Law Number 7 of 1971 concerning Archival Principal Provisions.

In the history of Indonesia, the growth of archival regulations has begun since the Dutch colonial era. An archival regulation that was very meaningful and very influential in Indonesia's archiving system was the law that regulated the state treasury called Indische Comptabiliteit Wet (ICW). This law has been basically still valid until now, so regulations in the field of archiving must still pay attention to the provisions contained in ICW.

The law that specifically regulated the field of archiving for the first time was legislated in 1971, called Law Number 7 of 1971 that dealt with the Basic Provisions of Archives. As a law, this legal regulation regulated a very broad aspect, including the management of archives and institutions nationally. In it, there were the definitions of archives, archival organizations, archival staff, and the National Archives of the Republic of Indonesia as a national archiving and archival management agency (Law No. 7/1971: Article 1, Article 2, Article 6, and Article 8) .

The birth of Law No. 7 of 1971 concerning the Basic Provisions of Archives was followed by the issuance of Government Regulation No. 34 of 1979 concerning Depreciation of Archives. The regulation regulated the depreciation of archives widely within the state institutions and government agencies. It was obligatory for each government agency to depreciate its archives systematically by referring to the Archive Retention Schedule set by a relevant archiving agency as stated in Article 4 of Government Regulation No. 34 of 1979. In the event that the agency in question had not yet had an Archive Retention Schedule, then the file depreciation at that relevant agency could be carried in accordance to the circular of the Head of the Republic of Indonesia National Archives Number: $\mathrm{SE} / 02 / 1983$. The provisions of the Government Regulation were then followed by the issuance of various technical regulations stipulated by the Head of the Indonesian National Archives.

Legislation in the field of archiving concerning the management of company archives is published separately under the name of Law Number 8 of 1997 concerning Company Documents. The law emerged as a reaction to the implementation of file depreciation which was considered very slow, so the issuance of the regulation was expected to overcome the lag. However, the new law could not be implemented in an orderly manner because it contained several aspects that were contrary to the provisions of the court case. Law No. 8 of 1997 was an initiative of financial institutions incorporated in the national banking forum.

The development of filing regulations in Indonesia has shown a positive trend since this was marked by the birth of Law No. 43 of 2009 concerning Archives. This law has discussed the scope and breadth of archives that are more extensive and detailed. There was also the issuance of Government Regulation Number 28 of 2012 concerning the implementation of Law Number 43 of 2009 on archives. In fact, other regulations also emerged in order to complement the archival regulations in Indonesia, both ministerial regulations and the Head of the RI National Archives regulations, and other regulations relating to archives and archiving. The following discussions will compare archival regulations in Indonesia as contained in Law Number 43 of 2009 concerning Archives and those in Law Number 7 of 1971 concerning Archival Principal Provisions.

Historically, the birth of Law No. 43 of 2009 was a momentum and a step forward in the history of archives in Indonesia. This is because the birth of Law No. 43 of 2009 occurred 38 years after the enactment of Law No. 7 of 1971 concerning the basic provisions of archiving. In 1971, there was not much progress in archive management, but during the era of information technology and globalization like now, regulations related to archival issues have to be adjusted, because if they do not follow the changes, it is feared that many things could be detrimental to the country in terms of archives and archiving, resulting in many archival issues that are not accommodated in legislation so that they will harm all parties, both the concerned agencies and the country itself. It is an unavoidable fact that

To cite this document:

Rodin, R., Romiati, M. (2019). Analysis of development of archiving regulation from

time to time in Indonesia. Record and Library Journal, 5 (1), 90 - 105. 
archive and archiving issues are very crucial and urgent in the administration of the country. In term of looking at their considerations only, by comparing Law Number 43 of 2009 Chapters 1-5 with Law No. 7 of 1971, it could be clearly seen that Law No. 7 of 1971 has only two (2) considerations, namely the interests of future generations and administrative improvement. Both of these were taken into consideration with the birth of Law No. 7 of 1971 . However, it is different with Law No. 43 of 2009 where the basis for the issuance of Law No. 43 has 7 (seven) considerations, namely maintaining the sovereignty of the country, guaranteeing the availability of authentic and reliable archives, facing the challenges of globalization, supporting good and clean governance and improving public services, regulating archiving issues to be more comprehensive, organizing archives which are still not integrated, systemic, and comprehensive, and adjusting to the era changes. Based on this we see the importance of archives and archives in the life of the nation and state. All these considerations for the birth of Law No. 43 of 2009 basically want to emphasize that the management of archives and archiving should be adjusted to the changes of time, so that good management of archives can ensure the availability of archives and reliability, can guarantee the improvement of public services, and most importantly can provide a comprehensive and integrated national archiving system.

Furthermore, when we look at and analyze the comparison between Chapter 1 concerning the general provisions of Law No. 7 of 1971 and that of Law No. 43 of 2009, there are very striking and fundamental differences, which are due to the vast and detailed articles and sections described in Law No. 43 of 2009. In Law No. 7 of 1971 in Chapter 1 there are only 3 (three) articles, of which Article 1 has 2 (two) sections, and Article 2 has only 2 (two) sections. Then if we look in terms of the contents of every article, Law No. 43 of 2009 is more detailed with the descriptions of archives and archiving. On other contrary, in Law No. 7 of 1971 there is only the definition of archives and their functions, as well as the purpose of archiving. In the case of Law No. 43 of 2009, Article 1 consists of 31 sections that discuss various meanings relating to archives and archiving, the explanation of which starts from the understanding of archives to the archive search list (DPA). This shows how detailed the explanation in Law No. 43 of 2009 is mainly related to Article 1 only. Chapter 1 Law No. 43 of 2009 only discusses matters relating to archives and archiving. Meanwhile, the issues with intent and purpose are discussed in the next chapter. On other hand, Chapter 1 of Law No. 7 of 1971 covers the definition, function and purpose of archives and archiving.

In Article 2 of Law No. 7 of 1971, which is still included in Chapter 1, there are a discussion about the function of archives in 2 (two) sections, which only distinguishes between dynamic and static archives. As with Law No. 43 of 2009, the purpose of archiving is contained in a separate chapter, namely Chapter 2 which discusses the purpose, objectives, principles, and scope. If Law No. 7 of 1971 does not include the intent of the birth of the law, Law No. 43 of 2009 clearly states that the intent is to provide legal certainty in the implementation of national archives.

Chapter 2 of Law No. 7 of 1971 discusses the duties of the government in the matters of archives and archiving. Chapter 2 consists of 4 articles (Articles 4 to 7 ), where it is explained that in Article 4 archiving is the authority and responsibility of the government, especially related to the archives produced by state institutions and government agencies; therefore, the government is obliged to secure the archives produced by private institutions. Furthermore, in Article 5, it is explained that the government is trying to regulate the administration of dynamic archives, as well as collection, storage, maintenance, rescue, and the use of static archives. Article 6 touches on the duty of the government to enhance the quality of national tourism management by intensifying several businesses that can improve the quality of archives. Then, Article 7 discussed about issues relating to archival human resources (HR), both in terms of education, position, authority, and health insurance for archivists.

Chapter 2 of Law No. 43 of 2009 covers the intent, purpose, principle, and scope. It is divided into 3 (three) parts. The first part discusses the intent and purpose. The second part talks the principle and the third part discusses the scope. Article 2 only describes that the purpose of the law is to provide legal certainty in the implementation of national archives, whereas in Law No. 7 of 1971 there is no mention

To cite this document:

Rodin, R., Romiati, M. (2019). Analysis of development of archiving regulation from

time to time in Indonesia. Record and Library Journal, 5 (1), 90 - 105. 
of the purpose of the birth of the law.

Furthermore, Article 3 of Law No. 43 of 2009 describes 8 (eight) sections relating to the administration of archives. On the other side, in Law No. 7 of 1971, there is only 1 (one) verse whose purpose includes to ensure the safety of material accountability and material for national accountability. In Law No. 43 of 2009, Article 3 describes in detail the purpose of organizing archives. Then, Article 4 discusses the principles of organizing archives, consisting of 14 (fourteen) principles. Lastly, the third part of chapter 2 explains the scope of archiving.

Chapter 3 of Law No. 7 of 1971 deals with archival organizations. This chapter has only 1 (one) article, namely Article 8 which only explains that the government has formed an archival organization in both state institutions and central and regional government agencies which means that archiving matters only reaches level I in the provincial capital. If we refer to Article 1 of Law No. 43 of 2009, it is explained that regional archival institutions should come down to the second level, namely the regency / city capital. In Chapter 3 of Law No. 43 of 2009 concerning the implementation of archives, in Article 6, there are 4 (four) levels of responsible entities for the organization of archives, namely at the national level carried out by ANRI (National Archives of the Republic of Indonesia), at the provincial level carried out by provincial archiving institutions (now provincial archival services), at the regency / city level carried out by district / city archival institutions (now regency / city archival services), and at the tertiary level carried out by university archival institutions. This is certainly what distinguishes between Law No. 7 of 1971 and Law No. 43 of 2009 in terms of archival organization organizations (archival organizers). If in Law No. 7 of 1971 there are only 2 (two) archival organizations, namely ANRI and Regional Archives in the provinces, in Law No. 43 of 2009 there are 4 (four) archival organizers, namely ANRI, regional I archive agencies at the provincial, regional level II archives in the regency / city, then the university archival institutions at level three.

Chapter 3, besides explaining archiving organizers, also explains the policy set out in Article 7 which contains 11 (eleven) policies, which are not contained in Law No. 7 of 1971. Furthermore, Article 8 describes the development of archives from the national and regional levels to universities. Article 9 explains the purpose of archive management. Issues about policy, guidance, and management were absent in Law No. 7 of 1971.

In the second part of Chapter 3, Law No. 43 of 2009 discusses the construction of SKN (National Filing System), National Archives Information System (SIKN), and establishment of JIKN (National Archives Information Network). These three things become the very distinct differences in the matter of organizing archives after the legalization of Law No. 43 of 2009.

Chapter 3, the third part of Law No. 43 of 2009, still discusses the archival organizations. If in Law No. 7 of 1971 this archival organization matter is discussed in Chapter 3 only with one article, namely Article 8 and with only 2 (two) sections, in which there were only two archival institutions discussed, namely central and regional level I organizations, in Law No. 43 of 2009 archival organization matters are discussed in 4 (four) sections, which in section 1 it explained that archival organization consisted of archival units at the creators and archiving institutions. Archiving unit must be formed by every government institution, state enterprise (BUMN), and regional enterprise (BUMD). Furthermore, in section 3, it is explained that there are 4 archival institutions, namely ANRI, provincial archives, regency / city archives, and university archives.

Then Articles 17 and 18 discuss the archival unit, both its functions and duties. Meanwhile, Articles 19 to 29 discuss archival institutions which include their functions, duties and authorities. Then, Article 30 discusses the development of professional and competent human resources in the field of archiving. This is certainly different from Law No 7 of 1971 which does not explain in detail about the matters found in Articles 17 to 30 above.

Chapter 3 also explains about infrastructure facilities in the administration of archives. This is stated in Articles 31 and 32. Subsequently, it is discussed about the protection and rescue of archives contained in Articles 33, 34 and 35. Then, part of organizing archives is the archival socialization which is discussed in Article 36. Furthermore, the most important part in organizing archives is

To cite this document:

Rodin, R., Romiati, M. (2019). Analysis of development of archiving regulation from

time to time in Indonesia. Record and Library Journal, 5 (1), 90 - 105. 
cooperation issues contained in Article 37. Funding is also one of the most important parts in the implementation of this archival management.

Based on the above explanation relating to Chapter 3 of Law No. 43 of 2009, it described in detail the implementation of archives, in which the discussion includes several articles and sections. This is of course very different from Law No. 7 of 1971 which only addresses archival organizations, which is only discussed in one article, namely Article 8.

Chapter 4 of Law No. 43 of 2009 discusses the management of dynamic archives, while Chapter 4 of Law No. 7 of 1971 deals with the obligation of archiving. The management of dynamic archives in Law No. 43 of 2009 covers Articles 40 to Article 58, where the domain of the discussion is the scope, implementation, use and maintenance, depreciation of archives, vital archives, and obligations of the creator of the archive. If we analyze Chapter 4 in Law No. 43 of 2009, it is clear that the discussion of regulations relating to the problem of dynamic file management is clearly explained, in detail and in detail in several sections, articles and sections. Meanwhile, Chapter 4 of Law No. 7 of 1971 dealing with the obligation of archving is only discussed in two articles (six sections). Discussion of the obligations of archival creators is discussed separately in Chapter 4 of Law No. 43 of 2009.

Chapter 5 of Law No. 43 of 2009 discusses the management of static archives, while Chapter 5 of Law No. 7 of 1971 discusses criminal provisions. The management of static archives in Law No. 43 of 2009 covers the scope and implementation which includes acquisition, processing, preservation, and static archival access, the discussion of which starts from Article 59 to Article 67. This shows how detailed the discussion about this static archive matter is. On the other hand, in Law No. 7 of 1971 there is no detailed discussion regarding the management of both dynamic and static archives.

Based on the comparative analysis above, it can be understood that the regulation on archiving matters in Law No. 43 of 2009 is more complete and detailed when compared to Law No. 7 of 1971. This is certainly an advanced step in terms of the administration of archives and archiving matters in Indonesia. Therefore, it can be understood that the dynamics of the development of archive regulations in Indonesia from time to time showed a positive trend. Even long before Indonesia's independence in 1945, in the Dutch colonial period regulations were applied to regulate this archiving matters. Therefore, the development of filing regulations is certainly a legal umbrella for archiving dynamics in Indonesia.

\section{Conclusion}

The history of archival management in Indonesia is very distinctive, emanating from the archival system that was originally attached to the activities of religious institutions in the Western filing system. Penetration of Western culture along with the development of the Dutch colonial government in Indonesia had resulted in the thick influence of the Dutch archiving system in Indonesia, and the attachment of Indonesian archival institutions to the World Archives Council has caused the effect of the Western archiving system to become increasingly thick.

The development of archive legality in Indonesia also indicates a strong influence of Dutch archive management. The substance of the provisions of the state treasury law "Indische Comptabiliteit Wet" (ICW) must still be carefully considered in the formulation of archival legislation so as not to clash with legal provisions in proving cases in court.

The legislation in the field of archiving in Indonesia is quite complete, but it cannot be implemented effectively because in it there are still many regulations that are not compatible and there is still a lack of understanding and awareness of the importance of archives. Therefore, policy makers must sit together to discuss this matter so that an agreement can be reached in order to guarantee the implementation of regulations relating to archival matters in Indonesia.

\section{References}

Abriani, N., dkk. (2018). Tata Kelola Arsip Kantor Desa di Wilayah Kecamatan Sumbang Kabupaten Banyumas dalam Mewujudkan Tertib Arsip Desa. Khazanah Jurnal Pengembangan Kearsipan, 
$11(1), 13-25$.

Barthos, B. (2003). Manajemen kearsipan untuk lembaga negara, swasta dan perguruan tinggi.

Jakarta : Bumi Aksara

Dutch East Indies. (2008). Regerings-almanak Nederlandsch-Indië. 1815-1942 = Governmental Almanac of the Netherlands East Indies 1815-1942. Den Haag : Centraal Bureau voor Genealogie. Ignatius, W. (2006). Kompetensi sekretaris profesional. Yogyakarta: Andi.

Indonesia. (1971). Undang-undang Nomor 7 Tahun 1971 tentang Ketentuan-ketentuan Pokok Kearsipan. Jakarta: Arsip Nasional Republik Indonesia.

Indonesia. (1999). Undang-undang Nomor 8 Tahun 1999 tentang Pemerintahan Daerah. Jakarta: Departemen Dalam Negeri RI.

Indonesia. (2009). Undang-undang Nomor 43 tahun 2009 tentang Kearsipan. Jakarta: Arsip Nasional Republik Indonesia.

Indonesia. (2012). Peraturan Pemerintah Nomor 28 Tahun 2012 tentang Pelaksanaan Undang-undang Nomor 43 tahun 2009 tentang Kearsipan. Jakarta: Arsip Nasional Republik Indonesia.

Indonesia. (1979). Peraturan Pemerintah Nomor 34 Tahun 1979 tentang Penyusutan Arsip. Jakrta: Arsip Nasional Republik Indonesia.

Indonesia. Keputusan Presiden Nomor 26 Tahun 1974 tentang Arsip Nasional Republik Indonesia. Jakrta: Arsip Nasional Republik Indonesia.

Indonesia. (1990). Keputusan Menteri Pendayagunaan Aparatur Negara Nomor 36 Tahun 1990 tentang Angka Kredit bagi jabatan Arsiparis. Jakarta: Departemen Pendayagunaan Aparatur Negara.

Indonesia. (2002). Keputusan Menteri Pendayagunaan Aparatur Negara Nomor 09/KEP/M.PAN/2/2002, Tahun 2002 tentang Jabatan Arsiparis dan Angka Kreditnya. Jakarta: Kementerian Pendayagunaan Aparatur Negara

Indonesia. (1974). Keputusan Presiden Nomor 26 Tahun 1974 tentang Arsip Nasional Republik Indonesia.

Kepala ANRI. (1981). Surat Edaran Kepala Arsip Nasional Nomor: SE/02/1981 tentang Penanganan Arsip Inaktif sebagai Pelaksanaan Ketentuan Peralihan Peraturan Pemerintah tentang Penyusutan Arsip. Jakarta: Arsip Nasional Republik Indonesia.

Laksono, R. (2017). Pemanfaatan Teknologi Digital dalam Proses Alih Media Arsip Statis. Diplomatika Jurnal Kearsipan Terapan, 1(1), 47-60.

Lolytasari. 2015. Penyusutan Arsip Perguruan Tinggi dalam Upaya Penyelamatan Arsip. Record And Library Journal Volume 1, Nomor 1, Januari - Juni 2015, hal. 26-38.

Patrick, N., \& Vivan, F. T. (2006) The management of public records and archives in the member countries of ESARBICA, Journal of the Society of Archivists, 21(1), 57-83. doi: $10.1080 / 00039810600691288$

Putranto, W. A. (2017). Pengelolaan Arsip Di Era Digital: Mempertimbangkan Kembali Sudut Pandang Pengguna. Diplomatika Jurnal Kearsipan Terapan, 1(1), 1-11.

Regeering Almanak Jilid II Tahun 1900-1942

Regering Almanak tahun 1905

Syauki, H. (2014). Sejarah Kearsipan. Tangerang Selatan: Universitas Terbuka.

Sedarmayanti. (2008). Manajemen Sumber Daya Manusia. Jakarta: Grasindo.

Suyadi. (2011). Indonesia harus belajar banyak mengelola arsip pada Belanda. Makalah dalam dalam acara diskusi "Buku: Gerakan Membaca dan Budaya Arsip". Padang: Komunitas Padang Membaca. Diunduh dari https://news.detik.com/berita/1683045/indonesia-harus-belajar-banyakmengelola-arsip-pada-belanda

The Liang Gie. (2000). Administrasi Perkantoran Modern.Yogyakarta: Liberty.

To cite this document:

Rodin, R., Romiati, M. (2019). Analysis of development of archiving regulation from

time to time in Indonesia. Record and Library Journal, 5 (1), 90 - 105. 